\title{
A Novel Germline Mutation in the von Hippel-Lindau Gene in Patients in Kuwait
}

\author{
Suad AlFadhli ${ }^{a}$ Matra Salim $^{a}$ Sadiqa Al-Awadi ${ }^{\mathrm{b}}$ \\ aDepartment of Medical Laboratory Sciences, Faculty of Allied Health Sciences, Kuwait University and \\ ${ }^{b}$ Kuwait Medical Genetic Centre, Maternity Hospital, Kuwait
}

\section{Key Words}

von Hippel-Lindau disease · Polymerase chain reaction-single strand conformation polymorphism

\begin{abstract}
Objective: To determine the germline mutation in an extended family in which 1 member was diagnosed clinically with von Hippel-Lindau (VHL) disease and to investigate 3 generations of the family. Subjects and Methods: The polymerase chain reaction-single strand conformation polymorphism sequencing techniques were used to identify the germline mutation in the $V H L$ gene in the patient and also to study 9 other members of the extended family over 3 generations. Results: The patient and 3 other members of the family were shown to have the same mutation in the splice donor site of the first intron. The mutation was identified as IVS1 $+1 \mathrm{G} \rightarrow \mathrm{T}$. Conclusion: The findings of this study indicate the presence of VHL mutation in a Kuwaiti family with Arab parentage. It is hoped that the study would contribute to understanding the types of mutation in VHL in the Middle East. Its early detection and diagnosis would help in genetic counseling of VHL patients.
\end{abstract}

Copyright @ 2004 S. Karger AG, Base

\section{Introduction}

Von Hippel-Lindau (VHL) disease is an autosomal dominant familial tumor syndrome. $V H L$ gene is a tumor suppressor gene isolated and localized at 3p25.5 [1, 2]. The basis of familial inheritance of $V H L$ is a germline mutation in this gene. This results in great risk of developing retinal and central nervous system hemangioblastoma as well as kidney cysts and clear cell carcinoma, cyst adenomas of other organs and pheochromocytomas [3-5]. The mutation spectrum of $V H L$ is heterogeneous with mutations scattered throughout most of the VHL gene. Although some recurrent mutations have been reported, most families have their own unique germline mutation [6-8]. VHL age of onset is variable and depends on the expression of the disease within an individual [9]. After DNA analysis has identified presymptomatic affected individuals in a family, carriers of the mutated VHL gene can be monitored closely and given appropriate treatment.

The prevalence of VHL has been estimated in the Western population to be between 1:35,000 and 1:40,000 $[2,10]$. Identifying such patients has been problematic as it involves comprehensive screening of all potentially affected family members. In addition, the prevalence of the genetic defect in the Middle Eastern population is

Dr. Suad AlFadhli, Faculty of Allied Health Sciences

Department of Medical Laboratory Sciences, Kuwait University

PO Box 31470, 90805 Sulaibekhat (Kuwait)

Tel +965944 5422, Fax +9654833631

E-MailSuadq8@yahoo.com or s.alfadhli@hsc.kuniv.edu.kw 


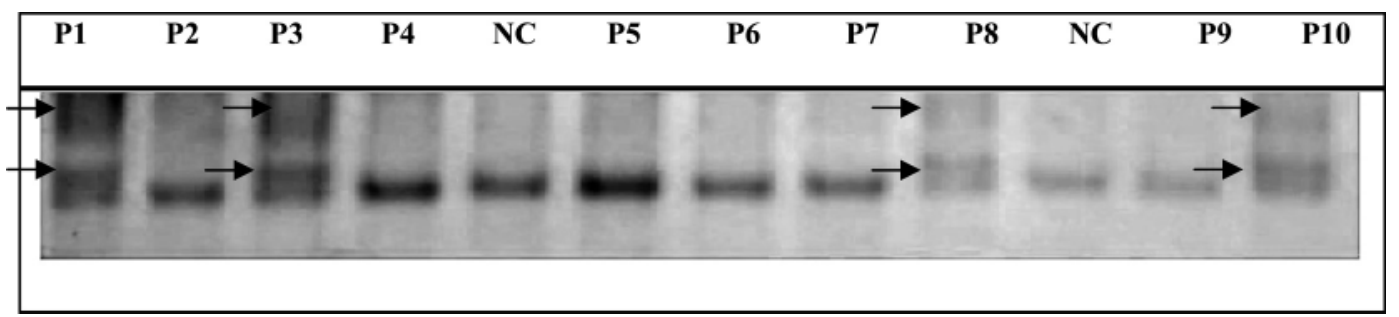

Fig. 1. SSCP results for all 10 screened members of the two families simplified as P1-10. Arrows indicate in patients $\mathrm{P} 1,3,8$ and 10 the extra band in the mutated DNA due to conformation polymorphism. $\mathrm{NC}=$ Normal control.

uncertain $[1,7,11-14]$. This is partly due to the fact that the nature of the mutations involved in VHL in Middle Eastern Arabs has not been determined. Therefore, the genetic mutation in one extended Kuwaiti family of 3 generations was characterized using polymerase chain reaction-single strand conformation polymorphism (PCRSSCP).

\section{Subjects and Methods}

\section{Subjects}

Ten members ( 7 male, 3 female) of 3 generations ( 2 grandparents, 2 parents and 6 children) of an Arabic-Persian family, of which 1 was clinically diagnosed with VHL disease, were recruited for the study. Five milliliters of EDTA blood was withdrawn once from this patient, 9 other members of the family and 15 controls $(8$ male, 7 female). Genomic DNA was extracted from the blood samples immediately.

\section{DNA Extraction and PCR}

Genomic DNA from blood samples was isolated by proteinase $\mathrm{K}$ digestion and phenol-chloroform extraction as previously described [15]. The cloned portion of VHL cDNA has three exons of 852 nucleotides [16]. Five sets of primers covering the three exons and the exon-intron boundaries were used [6]. The oligonucleotide primers were synthesized and supplied by Genelink (New York, USA, www.genelink.com). Each PCR for all exons and exon-intron boundaries was performed using $100 \mathrm{ng}$ genomic DNA, $1 \times$ PCR buffer (Perkin Elmer, USA), $10 \mathrm{pmol}$ of each PCR primer, $25 \mu \mathrm{mol} / \mathrm{l}$ deoxynucleoside triphosphate, $2.0 \mathrm{mmol} / 1 \mathrm{MgCl}_{2}$, and $0.25 \mathrm{U}$ Taq polymerase (Perkin Elmer) in a total volume of $50 \mu \mathrm{l}$. The PCRs were performed on a DNA thermal cycler (9700 Perkin Elmer) using the following parameters: first one denaturation step at $95^{\circ} \mathrm{C}$ for $3 \mathrm{~min}$, then 35 cycles of denaturation at $95^{\circ} \mathrm{C}$ for $1 \mathrm{~min}$, annealing at $58^{\circ} \mathrm{C}$ for $1 \mathrm{~min}$, and elongation at $72^{\circ} \mathrm{C}$ for $1 \mathrm{~min}$. Then a final step of 10 min at $72^{\circ} \mathrm{C}$. Ten microliters of the PCR product was checked on $1 \%$ agarose.

\section{Single Strand Conformation Polymorphism}

SSCP analysis was performed by mixing $3 \mu$ of the PCR reaction with $3 \mu \mathrm{l}$ of stop-solution (10 $\mathrm{mM} \mathrm{NaOH}, 95 \%$ formamide, $0.05 \%$ xylene cyanol, $0.05 \%$ bromophenol blue), heated to $95^{\circ} \mathrm{C}$ for $5 \mathrm{~min}$, and chilled on ice for $6 \mathrm{~min}$. The entire mixture was then loaded onto a horizontal nondenaturing $0.9 \mathrm{~mm} \times 50 \mathrm{~cm} \times 21 \mathrm{~cm}$ gel. This gel was $60 \mathrm{ml}$ of $10 \%$ polyacrylamide with $5 \%$ glycerol, $48 \mu \mathrm{l}$ of tetramethylethylenediamine and $380 \mu \mathrm{l}$ of $20 \%$ (w/v) ammonium persulfate. The gel was run at $250 \mathrm{~V}$ and $45 \mathrm{~W}$ overnight at room temperature with $1 \times$ Tris/borate/EDTA running buffer. The resulting bands were visualized by silver nitrate staining.

\section{Silver Nitrate Staining}

The gels were fixed in two changes of fixation solution (10\% ethanol, $0.5 \%$ acetic acid) each for $5 \mathrm{~min}$ with gentle shaking. They were stained for $15 \mathrm{~min}$ in freshly prepared $0.1 \%$ silver nitrate and rinsed briefly with distilled water. Gels were then incubated in developing solution $(1.5 \% \mathrm{NaOH}, 0.1 \%$ formaldehyde) for $30 \mathrm{~min}$. Finally the gels were treated with $0.75 \% \mathrm{Na}_{2} \mathrm{CO}_{3}$ solution for $10 \mathrm{~min}$, sealed in a plastic bag and photographed.

\section{DNA Sequencing}

The SSCP-positive samples were amplified by PCR in a total volume of $50 \mu$ l. The PCR product was ethanol-precipitated and dissolved in $15 \mu \mathrm{l}$ of sterile $\mathrm{dH}_{2} \mathrm{O}$. Four microliters of the cleaned PCR product was mixed with $3.2 \mu \mathrm{l}(1 \mathrm{pmol})$ of either the forward or the reverse primer, and $8 \mu \mathrm{l}$ of the dye terminator ready sequence reaction mix (Prism ${ }^{\mathrm{TM}}$ Ready Reaction Big Dye ${ }^{\mathrm{TM}}$ Terminator Cycle Sequencing Kit; Perkin Elmer). The sequencing reaction was then carried out in a 9700 thermocycler programmed to 25 cycles of $96^{\circ} \mathrm{C}$ for $10 \mathrm{~min}, 50^{\circ} \mathrm{C}$ for $5 \mathrm{~s}$, and $60^{\circ} \mathrm{C}$ for $4 \mathrm{~min}$. The sequencing reaction was ethanol precipitated and $25 \mu 1$ of HiDi formamide was added to the pellet, mixed, heated for $2 \mathrm{~min}$ at $95^{\circ} \mathrm{C}$, kept on ice until the sequencing, run on an automated DNA sequencer (ABI3100; Applied Biosystem, USA).

\section{Results}

Of the 10 members of the family, SSCP showed an extra band in 4 of the children ( 3 male, 1 female) including the patient (fig. 1). The remaining family members and normal controls did not show any such band. Representative sequencing spherograms of normal subjects and the VHL patient are shown in figure 2. 


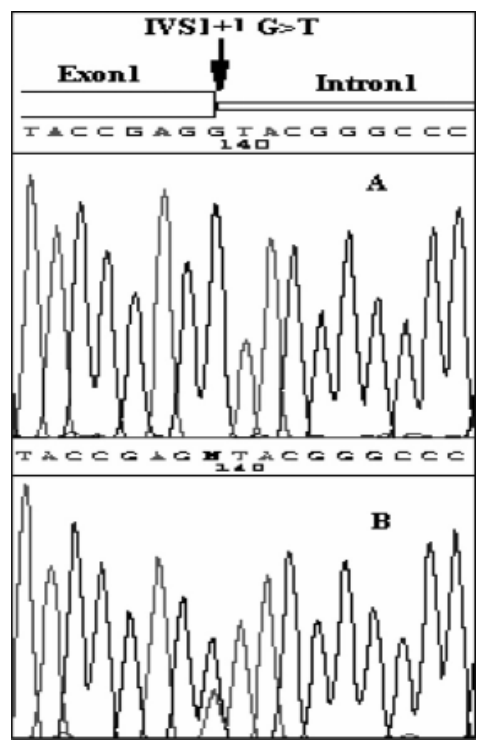

Fig. 2. Sequencing results using the ABI3100 automated sequencer showing the G-T mutation in the first nucleotide of intron one, IVS1 $+1 \mathrm{G} \rightarrow \mathrm{T}$, where $\mathrm{A}$ is the wild type and $\mathrm{B}$ is the mutant.

The mutation in the $V H L$ gene was found in nucleotide number one of the first intron, designated as IVS1 +1 $\mathrm{G} \rightarrow \mathrm{T}$ mutation. This nucleotide is in the splice donor site of intron 1. The origin of the mutation was from the Arabic side of the family. The patient with VHL mutation was 39 years old, while the other 2 males were 32 and 20 years old, and the female was 24 years. The patient aged 39 years died only a few weeks before completion of the study.

\section{Discussion}

As previously noted, the age of onset of VHL is variable and depends on the expression of the disease within an individual [9]. The clinical diagnosis depends on the onset of the symptoms; therefore gene carriers cannot be identified prior to manifestation of disease complications especially if they lack a family history of the disease. Hence, late diagnosis or misdiagnosis of this disease might result in a severe outcome, and most probably premature death. Using the PCR/SSCP/sequencing method, we confirmed the clinical diagnosis of the primary patient who was diagnosed with VHL disease by the identification of the single nucleotide substitution in the exon one- intron one boundary from $\mathrm{G}$ to $\mathrm{T}$, which is nucleotide IVS1 $+1 \mathrm{G}>\mathrm{T}$. This nucleotide is an intron splice donor for intron 1, which is the first such mutation to be identified not only in Kuwait, but also among the 908 screened families worldwide [6, 7, 11-14]. A similar position mutation was identified, but on the intron 2-exon 3 boundary at nucleotide $677-1$, which is an intron splice acceptor for exon $3[11,14]$.

The prevalence of $V H L$ has been estimated to be between 1:35,000 and 1:40,000 [2, 10]. Applying this to the Middle Eastern region, there should be between 25 and 30 patients with VHL disease in Kuwait, but the necessary comprehensive screening of all potentially affected family members has made identifying such patients problematic. The screening approach used in this study, PCR/ $\mathrm{SSCP} /$ sequencing, is a diagnostic tool which should be adopted to improve the diagnosis of VHL disease in patients without an established disease history, as well as provide presymptomatic diagnosis in relatives of VHL patients with known mutations.

\section{Conclusion}

The findings of this study indicate the presence of VHL mutation in a Kuwaiti family with Arab parentage. It is hoped that the study would contribute to understanding the types of mutation in VHL in the Middle East. Its early detection and diagnosis would help in genetic counseling of VHL patients.

\section{Acknowledgments}

We would like to thank the members of the families who participated in this study and especially A. Al-Wadaani and F. Mustafa for their assistance. This study was supported by Kuwait University grant No. NM00/01. 


\section{References}

$\checkmark 1$ Hosoe S, Brauch H, Latif F, Glenn G, Daniel L, Bale S, Choyke P, Gorin M, Oldfield E, Berman A: Localization of the von Hippel-Lindau disease gene to a small region of chromosome 3. Genomics 1990;8:634-640.

-2 Maher ER, Bentley E, Yates J, Latif F, Lerman M, Zbar B, Affara N, Ferguson-Smith M: Mapping of the von Hippel-Lindau disease locus to a small region of chromosome $3 p$ by genetic linkage analysis. Genomics 1991;10:957-960.

3 Maher ER, Yate RW, Harris R, Benjamin C, Harris R, Moore AT, Ferguson-Smith MA: Clinical features and natural history of von Hippel-Lindau disease. Q J Med 1990;77:113.

4 Maher ER, Iselius L, Yates JR, Littler M, Benjamin C, Harris R, Sampson J, Williams A, Ferguson-Smith MA, Morton N: Von HippelLindau disease: A genetic study. J Med Genet 1991;28:443-447.

$\checkmark 5$ Moore AT, Maher ER, Rosen P, Gregor Z, Bird AC: Ophthalmological screening for von Hippel-Lindau disease. Eye 1991;5:723-728.

6 Chen F, Kishida T, Yao M, Hustad T, Glavac D, Dean M, Gnarra JR: Germline mutations in the von Hippel-Lindau disease tumor suppressor gene: Correlations with phenotype. Hum Mutat 1995;5:66-75.
7 Hes F, Zewald R, Peeters T, Sijmons R, Links T, Verheij J, Matthijs G, Leguis E, Mortier G, van der Torren K, Rosman M, Lips C, Pearson $\mathrm{P}$, van der Luijt R: Genotype-phenotype correlations in families with deletions in the von Hippel-Lindau ( $V H L$ ) gene. Hum Genet 2000; 106:425-431.

$>8$ Olschwang S, Richard S, Boisson C, Giraud S, Laurent-Puig P, Resche F, Thomas G: Germline mutation profile of the $V H L$ gene in von Hippel-Lindau disease and in sporadic hemangioblastoma. Hum Mutat 1998;12:424-430.

9 Maddock IR, Moran A, Maher ER, Teare MD, Norman A, Payne SJ, Whitehouse R, Dodd C, Lavin M, Hartley N, Super M, Evans DG: A genetic register for von Hippel-Lindau disease. J Med Genet 1996;33:120-127.

10 Neumann HP, Wiestler OD: Clustering of features and genetics of von Hippel-Lindau syndrome. Lancet 1991;338:258.

11 Crossey PA, Richards F, Foster K, Green JS, Prowse A, Latif F, Lerman MI: Identification of intragenic mutations in the von Hippel-Lindau disease tumour suppressor gene and correlation with disease phenotype. Hum Mol Genet 1994;3:1303-1308.
12 Gnarra JR, Tory K, Weng Y, Schmidt L, Wei $\mathrm{MH}, \mathrm{Li} \mathrm{H}$, Latif F: Mutations of the $V H L$ tumour suppressor gene in renal carcinoma. Nat Genet 1994;7:85-90.

13 Whaley JM, Naglich J, Gelbert L, Hsia YE, Lamiell JM, Green JS, Collins D: Germ-line mutations in the von Hippel-Lindau tumorsuppressor gene are similar to somatic von Hippel-Lindau aberrations in sporadic renal cell carcinoma. Am J Hum Genet 1994;55:10921102.

14 Zbar B, Kishida T, Chen F, Schmidt L, Maher ER, Richards FM, Crossey PA: Germline mutations in the von Hippel-Lindau disease $(V H L)$ gene in families from North America, Europe, and Japan. Hum Mutat 1996;8:348357.

15 Sambrook J, Fritsch EF, Maniatis T: Molecular Cloning: A Laboratory Manual, ed 2. Cold Spring Harbor, Cold Spring Harbor Laboratory Press, 1989, vol 1, pp 9.16-9.19.

16 Latif F, Tory K, Gnarra J, Yao M, Duh FM, Orcutt ML, Stackhouse T: Identification of the von Hippel-Lindau disease tumor suppressor gene. Science 1993;28:260:1317-1320. 